The Market Turn: From Social Democracy to Market Liberalism

By Avner Offer

All Souls College, University of Oxford

avner.offer@all-souls.ox.ac.uk

(December 2016) 


\begin{abstract}
Social democracy and market liberalism offered different solutions to the same problem: how to provide for life-cycle dependency. Social democracy makes lateral transfers from producers to dependents by means of progressive taxation. Market liberalism uses financial markets to transfer financial entitlement over time. Social democracy came up against the limits of public expenditure in the 1970s. The 'market turn' from social democracy to market liberalism was enabled by easy credit in the 1980s. Much of this was absorbed into homeownership, which attracted majorities of households (and voters) in the developed world. Early movers did well, but easy credit eventually drove house prices beyond the reach of younger cohorts. Debt service diminished effective demand, which instigated financial instability. Both social democracy and market liberalism are in crisis.
\end{abstract}




\section{The Market Turn: From Social Democracy to Market Liberalism ${ }^{1}$}

During the twentieth century, social outcomes in developed economies were shaped by two financial innovations (figure 1). The magnitudes are those of the UK.

\section{FIGURE 1 HERE}

The first was the rise of public expenditure, which more than doubled as a proportion of national income between 1920 and 1980. The second was a rise of household debt from around 50 percent of income in 1980 to three times as much in 2008, most of it incurred for homeownership. The rise of public expenditure is the 'social democracy' of the title. It was a fiscal innovation which reduced inequality. ${ }^{2}$ The rise of household debt was an aspect of the 'market turn' which began in the 1980s, as a quest to privatise the delivery of government functions. This took place under the auspices of 'market liberalism', a pervasive political and social movement that holds up buying and selling as a norm for human relations. ${ }^{3}$ It increased inequality. Market liberalism was facilitated by a monetary innovation, the deregulation of credit, which permitted large increases in household borrowing. This expansion of credit left retail prices unaffected, but worked to inflate house prices and other asset values. Before the 1980s incomes and house prices tended to move together, but from then onwards real house prices approximately doubled in a group of fourteen advanced countries. ${ }^{4}$ Inequality also rose from the 1980 s onwards, redistributing wealth and income from consumers to lenders, and from the young to the old, a process which still continues.

\footnotetext{
${ }^{1}$ Revised from the author's Tawney Lecture at the Economic History Society annual conference, Cambridge, 3 April 2016. Thanks to Shamim Gammage for excellent technical assistance, and to Siobhan McAndrew for transcribing the lecture.

${ }^{2}$ Piketty, Capital in the twentieth century, ch. 9; Alvaredo et al., 'The top 1 percent'.

${ }^{3}$ As defined in Offer and Söderberg, The Nobel Factor, p. 1.

${ }^{4}$ Steger et al. 'No Price Like Home', fig. 15, p. 19; Hudson, The bubble and beyond, ch. 8.
} 
Both innovations arose to satisfy fundamental aspirations. Social democracy strove to provide employment, education, healthcare, social insurance, housing, and physical infrastructure. Market liberalism held out property ownership as an alternative source of economic security. In its time, each of these two innovations became a new social settlement. Both were embraced as bi-partisan democratic strategies, and both were aligned with voter majority interests. That accounts for their durability. They were not parochial to the UK: similar developments took place across the developed world, at different times, paces and levels. Both eventually pushed against their limits, and moved into crisis.

Social democracy and market liberalism are two visions of society underpinned by different ethical norms. These norms however are captured by the single concept of a 'Just World Theory'. Such doctrines state that everyone gets what they deserve. ${ }^{5}$ The statement can also be reversed: everyone deserves what they get. Social democracy arose out of the efforts of nineteenth-century political radicalism and the twentieth-century labour movement. It drew on the ethics of classical economics, whose doctrines were studied and taught in the first century after Adam Smith's Wealth of Nations (1776). In this approach, value was created by three factors of production - labour, capital, and land. For the first two, income was the incentive for effort. Rent, the reward for landownership, was paid by the other two factors. Land was productive, but not its ownership: if the owner departed, the land was still there. For its owners, rising land values were a free lunch. North Oxford houses (like the author's) acquire their value from their location. The identity of their owner does not matter. For Adam Smith and David Ricardo, landownership could be taxed with no effect on productive

\footnotetext{
${ }^{5}$ Rubin, 'Who believes in a just world?'; Lerner, Belief in a just world; The concept is used differently here, as in Offer and Söderberg, Nobel factor, pp. 3-4.
} 
incentives. ${ }^{6}$ This argument was restated by the American radical Henry George, who acquired a large following in the 1880s for his doctrine of the 'single tax', namely paying for government mostly by means of taxes on land. ${ }^{7}$

For the neoclassical economists who followed the classics after 1870, value did not arise from production, but from subjective preferences and effective demand. Some of them were motivated by an aversion to Henry George and his doctrines. ${ }^{8}$ On the production side, they recognised only two factors, capital and labour, and they folded land into capital, treating the two factors as substitutes. Landownership was a service to production, like capital and labour. Everyone was entitled to be paid at least their marginal contribution to production, including the sleeping owners of assets. In contrast, the neoclassicals rejected the classical concept of an unearned increment, which was a tenet of nineteenth-century liberalism. ${ }^{9}$ In 1962, Milton Friedman stated that, 'The ethical principle that would directly justify the distribution of income in a free market society is, "To each according to what he and the instruments he owns produces",. ${ }^{10}$ Everyone deserved what they got; in the case of property owners, by virtue of ownership and nothing else. The rising value of Oxford houses was ethically deserved. There was no free lunch available to be taxed. ${ }^{11}$

After World War II, neoclassical economics was theorised elaborately, and reached out for the prestige of science: the Nobel Prize in economics, awarded every year from 1969 onwards, was dominated by neoclassicals. ${ }^{12}$ Entitlements arose from labour and from property rights, however acquired. Whatever people brought into the market, their inheritance and initial endowments of property and talent, was ethically deserved. What they

\footnotetext{
${ }^{6}$ O’Brien, Classical Economists, ch. 5.

${ }^{7}$ George, Progress and Poverty.

${ }^{8}$ Gaffney and Harrison, Corruption of economics; for historical background, Offer, Property and politics, chs. 12, 16, 19, 22.

${ }^{9}$ Shehab, Progressive Taxation.

10 Friedman and Friedman, Capitalism and freedom, 161-2

${ }^{11}$ Friedman, No such thing as a free lunch.

12 Offer and Söderberg, Nobel factor, ch 5.
} 
took out as wages, profits, and rent, was also ethically deserved, with no further obligation to anyone. If perfect competition was assumed, then rents would be competed away, and unearned increments could not arise. The free market economy was both efficient and just, a natural order which it was futile to resist.

Like market liberalism, social democracy also had its roots in the movement for political and social emancipation which began with the Reformation and the enlightenment. The principles of equality before God and the law were followed by voting for adults and citizenship for all. Social democracy was a 'Just World Theory' but with different premises: entitlement to economic security was acquired by citizenship, and everybody was entitled equally. As in classical economics, the point of departure was production, so alongside unproductive rentiers, there was also some mistrust of social outsiders and other nonproducers. $^{13}$

The social democratic orientation was communitarian, reciprocal, and domestic. Per Albin Hansson, leader of Swedish Social Democratic Party, defined social democracy in 1928 as 'The People’s Home’.

The basis of the home is commonality and mutuality. A good home is not aware of any privileged or slighted, no darlings and no stepchildren. You see no one despise the other, no one who tries to gain advantage of others... In the good home you find equality, compassion, cooperation, helpfulness. ${ }^{14}$

This communitarian warm glow doctrine is underpinned by the norm of mutual regard. ${ }^{15}$ Tough-minded critics responded by saying that that equality and efficiency were not consistent with each other. ${ }^{16}$ For example, John Rawls's influential treatise, A Theory of Justice (1971) argued that inequality was justified if it helped to raise the condition of the

\footnotetext{
${ }^{13}$ Offer and Söderberg, Nobel factor, pp. 4-8.

${ }^{14}$ Hansson, Swedish parliament, Andra kammarens protokoll nr 14-19 [second chamber debates], no. 3, 28 January1928, p. 11; Berman, 'The folkhem was a success story'.

${ }^{15}$ Offer, 'Between the gift and the market'.

${ }^{16}$ Okun, Equality and efficiency.
} 
worst off. Efficiency was achieved by means of unfettered market exchange. But how? not in the vernacular sense of getting more out of less. Rather, in general equilibrium and under an array of restrictive conditions, the pursuit of self-interest would scale up to an efficient social optimum, defined as Pareto efficiency, i.e. the absence of slack: nobody could improve their position without harming somebody else. The Arrow-Debreu-McKenzie model of general equilibrium (1954) encapsulated this result in the two theorems of welfare economics, which postulated that any general equilibrium was a Pareto optimum, and that a Pareto optimum could be attained from any initial distribution. Beyond the hypothetical choice of an initial distribution, equity was not a relevant option.

This notion of efficient market exchange was imaginary, and required some impossible prerequisites. Nevertheless, a trade-off between equity and efficiency has been a staple of economics textbooks since the 1970s, even of those that lean to the left. ${ }^{17}$ In recent years however the equity/efficiency trade-off has been empirically falsified. ${ }^{18}$ There is no indication that equality or high taxation are inimical to growth. The opposite may be true: the highly taxed and relatively equal societies of Scandinavia are among the richest in the world, while unequal societies with low taxation tend to be poor as well (the United States is a partial exception, which suffers from a great deal of poverty and stagnating incomes for the majority).

In practice the policy issue was not equity, but dependency over the life-cycle. For the utilitarian social planner, the central normative and policy issue was how to combine prosperity with security. The neoclassical principle of methodological individualism regards each person as a free-standing unit with something to sell. But reality is at odds: dependency on others is inescapable in the course of the life-cycle: there is motherhood, infancy,

\footnotetext{
${ }^{17}$ E.g. Stiglitz, Economics, p. 636; Samuelson and Nordhaus, Economics, pp. 810-812; Frank, Microeconomics and Behavior, pp. 665-67.

${ }^{18}$ Osberg, 'Equity/efficiency trade-off in retrospect'; Ostry et al., 'Redistribution, inequality, and growth'; Cingano, 'Trends in income inequality and its impact'; Dabla-Norris et al. 'Causes and consequences of income inequality'.
} 
childhood, education, illness, disability, unemployment, and old age. In these circumstances there may be no agency, no two feet to stand on, nothing to sell, no bargaining power, and restricted cognitive capacity. The welfare problem is how to transfer resources from producers to dependents over the life cycle.

The neoclassical solution was for individuals to make transfers to themselves across time. Three theories in particular elaborated this notion during the 1950s: life-cycle consumption (Modigliani and Brumberg in 1954), permanent income (Milton Friedman in 1957), and overlapping generations (Paul Samuelson in 1958). ${ }^{19}$ These transfers over the life cycle are achieved by borrowing, saving, and dis-saving in financial markets. This is shown to work in theory, albeit with certain restrictive assumptions, namely: (a) access to credit and to credible saving contracts; (b) that life-cycle contingencies are privately insurable; (c) costless transactions; (d) contracts are upheld costlessly; (e) perfect information for all time, and/or no cheating (which comes to the same thing).

It should be said that dependents in the early stage of life (infancy, childhood, education, motherhood) do not have the option to provide for themselves by this method. In these models, taxation is a 'deadweight cost' which distorts incentives, without reference to the benefits it might provide. ${ }^{20}$ The standard of efficiency is the imagined Arrow-Debreu model of general equilibrium. It implies that extending the scope of the market ('market completion') increases efficiency. This theoretical notion was refuted by the 'theory of the second best' back in 1956, but this refutation is also widely ignored. ${ }^{21}$ The policy implication of the neoclassical model is to promote markets for health, education, social insurance, and old age pensions.

\footnotetext{
${ }^{19}$ Modigliani, 'Life-Cycle, individual thrift'; Friedman, Theory of the consumption function; Samuelson, 'An exact consumption-loan model'.

${ }^{20}$ Hines, 'Three sides of Harberger triangles'; Offer and Söderberg, Nobel factor, pp. 170-173, 198-203.

${ }^{21}$ Lipsey and Lancaster, 'General theory of second best'.
} 
In contrast, for social democracy dependency is certain but its timing is unknown for any individual. Risk is not personal, but actuarial, and its aggregate magnitude is known. Hence the solution is collective risk pooling, underpinned by a norm of reciprocal obligation. The institutional instrument is not financial markets but a reciprocal 'club' or a state agency. ${ }^{22}$ The state can be viewed as a club of all its citizens. Transfers are not over time from individuals to themselves, but in the present from producers to dependents, mediated by a voluntary association or a state agency. As in Samuelson's model of overlapping generations, the transfers are cross-sectional from one generation to another in current time. There is no hoarding of financial claims: transfers are financed by pay-as-you-go progressive taxation, and are spent as they are raised. ${ }^{23}$ Since the 1970 s tax credits have been used to supplement wages in several countries. It is not clear how much this is a subsidy for workers, employers or lenders (to underpin debt service), and is probably all three. This is not an extension of social democracy but should be seen as an extension of market liberalism, to patch up its expanding inequalities. ${ }^{24}$

Despite the persistent advocacy of market provision, it is never noticed that financial markets are not large enough to support welfare transfers. ${ }^{25}$ Among financial assets, corporate bonds do not provide any advantage over government ones when adjusted for risk, and government bonds are pay-as-you-go in another guise. The United States has the most parsimonious welfare state of any developed country, and a large stock market. The Standard \& Poor index of 500 equities on the New York Stock Exchange encompasses the bulk of American traded equities by value. The revenue flows it recorded during the boom of the 1990s (covering most of USA dividend income) were a little below 5 percent of GDP a year (before transaction costs, which reduced payouts further). Federal transfer payments during

\footnotetext{
${ }^{22}$ Cornes and Sandler, The theory of externalities, pt. IV; Offer, Why has the public sector grown, pp. 3, 7.

${ }^{23}$ Barr, Welfare state as a piggy bank.

${ }^{24}$ Phelps, Rewarding work.

${ }^{25}$ Financial market advocacy, e.g. Feldstein, 'Rethinking social insurance'; Shiller, Finance and the Good Society.
} 
that period were more than twice as high, about 11 percent of GDP a year. ${ }^{26}$ Equity returns are not available for welfare transfers in any case - they mostly belong to the better off. ${ }^{27}$ When capital gains and losses are taken into account, stock market returns are volatile: at their peak in 1998 total returns (dividend income and capital gains) touched the level of federal revenues at 30 percent of GDP, but in 2003 the returns were negative, and losses amounted to almost to 20 percent of GDP. ${ }^{28}$ A simulation showed that over the period 18711999 in the United States, for pensions derived entirely from equity returns, the best outcome was almost six times higher than the worst one, depending on the timing of entry and exit. ${ }^{29}$

In contrast to stock markets, the tax base is large, stable and robust, comprising most of national income. With no need to lock in the future, transaction costs can be low. Welfare state pensions are not guaranteed by contract, and are an order of magnitude cheaper to administer than financial market ones. ${ }^{30}$ The rigidity of financial contracts offers an illusory security but such contracts are exposed to several forms of failure and default: in contrast, under social democracy, the contract is renegotiated periodically. The level of transfer embodies an equilibrium of current democratic preferences, and can change up or down to reflect prevailing norms. Welfare payments have a redistributive component, but they mostly represent insurance payouts.

Social democrats thus had no compunction about taxation. R. H. Tawney (18801962) for whom this lecture is named, was a founder of the Economic History Society, and also an advocate of social democracy. In 1941 he stated,

We must spend, not less, but more on education, health, housing, and the establishment of security against the contingencies of life. We do not intend,

\footnotetext{
${ }^{26}$ Offer, 'Economy of obligation', fig. 3, p. 25.

${ }^{27}$ Mian and Sufi, House of Debt, p. 18; Wolff, Top heavy, pp. 10-11, fig. 3-3.

${ }^{28}$ Offer, op. cit.

${ }^{29}$ Burtless, 'Social security privatisation and financial market risk', table 4.1, p. 66 .

${ }^{30}$ Offer, 'Economy of obligation', p. 20.
} 
therefore, to yield to the clamour for reduced taxation, but to maintain it and to use its proceeds for purposes essential to the general welfare. ${ }^{31}$

The social democratic project succeeded. Public expenditure increased from around 10 percent of GDP before the First World War, to between 40 and 50 percent in most advanced countries by the 1970s. It grew much faster than its host economies. Of that expenditure, typically between 60 and 70 percent was for health, education, and social insurance. In the 1980s, public expenditure stabilised as a share of GDP and remained at about the same level (around 30\% of GDP outside the USA) up to the financial crisis of $2008 .^{32}$

After 1970, inflation rose, productivity growth declined, and the core industrial countries began to de-industrialise. It was widely held that social democracy had been pushed to excess. ${ }^{33}$ But the case has never been nailed down. Our focus here is on something else, on what drove the transition away from social democracy, which we have called the market turn. The landmark event was the closing of the US Federal Reserve gold window on 15 August 1971, in response to domestic inflation and the Vietnam war; and the consequent collapse of the Bretton Woods international fixed exchange rate system. This had an unintended consequence-it set credit free from prior constraints. This liberalisation of credit is the key to what followed.

At this point, a brief digression is called for, on money and banking. What is money and where does it come from? After three hundred years of economic discourse, the question

\footnotetext{
${ }^{31}$ In Washington DC in 1941, cited by Goldman, Life of R. H. Tawney, p. 267.

32 Offer, 'Economy of obligation', fig. 1, p. 4; Offer and Söderberg, Nobel Factor, fig. I.1, p. 12.

${ }^{33}$ E.g. Bacon and Eltis, Britain's economic problem; Hirsch and Goldthorpe, Political economy of inflation; OECD, Welfare state in crisis.
} 
remains unsettled. ${ }^{34}$ There are two approaches, regulation by supply, and by demand. The prevailing common sense is that money is exogenous to the economy. Money is only a veil over economic fundamentals. It is rationed out by the sovereign or the central bank, it is scarce, and its quantity determines the price level, but not economic activity. The quantity in question can be gold or silver; lending on the security of commodities, funds abstracted from consumption by thrift, or reserves held at the central bank. The role of banks is intermediation: they borrow short from depositors, lend long to entrepreneurs, and bear the consequent risks arising from this 'maturity transformation'. ${ }^{35}$ By selecting the best projects, they perform a useful social function.

In contrast, endogenous money theory argues that the quantity of money expands or contracts in response to demand from credible borrowers. ${ }^{36}$ Deposits do not give rise to loans-it is loans that create deposits. Money is created when banks lend it out, as deposits are credited to borrowers. Before the 1970s, when most borrowing from banks was for business, overdrafts or lines of credit were the dominant form of lending and once agreed, were beyond the control of the lender or the central bank. ${ }^{37}$ Bankers created this money at the stroke of a pen. The conceptual difference is not hard and fast. Exogenous money theorists acknowledge that banks have discretion to expand lending as a ratio of their capital and central bank reserves (their 'leverage’). ${ }^{38}$

Most money only exists in bank accounts: currently, for example, some 97 percent of money in the UK. ${ }^{39}$ Apart from some leakage into cash and foreign transfers, any withdrawal

\footnotetext{
${ }^{34}$ Ryan-Collins et al., Where does money come from?

35 Diamond and Dybvig, 'Bank runs'.

${ }^{36}$ The term was coined by Kaldor, 'The new monetarism’, pp. 9, 12, 16; Moore, Horizontalists and verticalists; Palley, 'Horizontalists, verticalists, and structuralists'; Werner, 'Can banks individually create money'; idem, 'A lost century in economics'; Werner, 'Comment', p. 2; McLeay et al. 'Money creation'.

${ }^{37}$ Moore, Horizontalists and verticalists, pp. 24-5; In practice, Goodhart, 'Competition and credit control', pp. 2-4.

${ }^{38}$ Mishkin, Economics of money, ch. 14; Moore, Horizontalists and verticalists, ch. 2; Hotson, Respectable banking, ch. 5 .

${ }^{39}$ McLeay et al., 'Money creation', p. 2.
} 
ends up in another account, either at the same bank or elsewhere. ${ }^{40}$ If all banks expand their lending at a similar rate, then what goes out is likely to be matched by what comes in (if there had been only one bank, the money would never leave it). After settling balances with each other, banks need to make sure of operational liquidity, which is secured by borrowing from each other, from outside the banking system, or at the central bank. In the ordinary course of business, the central bank accommodated the commercial banks with whatever levels of reserves they required. ${ }^{41}$ The ability to create money does sound like a free lunch. In endogenous money theory, this capacity is only restricted by the supply of creditworthy borrowers.

But for more than two decades after 1945, this capacity for open-ended lending was circumscribed. 'Finance was caged.' ${ }^{42}$ Credit was rationed centrally. It was regulated tightly by governments and central banks. Housing, production, or exports received priority some of the time and the authorities often imposed quantity limitations on credit. They did this mostly to roll over government wartime debts, and to maintain the Bretton Woods system of fixed exchange rates. ${ }^{43}$ Managing credit centrally was tiresome and imprecise. By the end of the sixties, regulators had wearied of regulating, and the policy mood had changed. ${ }^{44}$

III

On Christmas Eve 1970, the Executive Director for Home Finance at the Bank of England, John Fforde, wrote an internal memo to senior colleagues to make the case for relaxing credit controls:

\footnotetext{
${ }^{40}$ Moore, Horizontalists and verticalists, pp. 51-52.

41 E.g., Sayers, Modern banking, pp. 103-11; Kareken, 'Monetary policy', p. 69, n. 1; p. 99; Moore, Horizontalists and verticalists, ch. 2, and pp. 88-92.

${ }^{42}$ Wolf, The shifts and the shocks, p. 349.

${ }^{43}$ Werner, Princes of yen; Werner, New paradigm; Monnet, 'Diversity in national monetary and credit policies'; Karaken, 'Monetary policy’; Offer, ‘Narrow banking’, pp. 165-166.

${ }^{44}$ Kareken, 'Monetary policy’; Goodhart, 'Competition and credit control’, pp. 3-8.
} 
He who argues for fundamental change must to some degree, be preaching a faith. If one does not believe that competition is capable of stimulating efficiency and innovation, then presumably one ought not to object to a permanent system of ceiling controls on banks. But if competition has any virtue, we ought not to have a system that stifles. ${ }^{45}$

This long memorandum offers an insight into the minds of policy makers. Deregulating credit was a leap of faith. 'If one has sufficient faith in market economics, one should conclude that the allocation of resources would be better than under our present arrangements.' Doubt was stifled by bluster: 'prolongation of the present system is inconsistent with the Bank's fundamental and correct view'. 'Fundamental and correct' is a statement of strong priors. Critics worried, wrote Fforde, that the policy might be 'a dangerous leap in the dark' ${ }^{46}$ They were not to be entirely dismissed, and he proposed to move slowly. But to no avail.

The reform, known as 'Competition and Credit Control' (CCC) came into effect on 16 September 1971, one month exactly after the closing of the American gold window. ${ }^{47}$ It replaced quantity controls with regulation by means of interest rates, and strove to create a single credit market to allow market forces free rein. ${ }^{48}$ CCC was aligned with the Conservative Prime Minister Edward Heath's dash for growth. But instead of industrial investment, it drove a consumer boom, with rising property values and imports. Within two years, sterling advances to UK borrowers rose two-and-a-half times, while property and finance (combined) increased their borrowings fourfold. ${ }^{49}$ Inflation rose, followed by industrial unrest. The Bank of England began to back-pedal in less than two years. Starting in July 1973, it brought credit back under control for the rest of the 1970s, at a level lower even

\footnotetext{
${ }^{45}$ Fforde, 'Banking system (and credit control)', fo. 6; Citations are from the archival copy, which has revealing annotations. The document is reproduced in Goodhart, 'Competition and credit control', pp. 15-22.

${ }^{46}$ Fforde, op. cit., fo. 12 [in Goodhart, p. 21]; Also Capie, Bank of England, pp. 486-88.

${ }^{47}$ Bank of England, 'Competition and credit control'; Capie, Bank of England, ch. 10; Goodhart, 'Competition and credit control'.

${ }^{48}$ Reid, Secondary banking crisis, chs. 3-6; Goodhart, op. cit.

${ }^{49}$ Reid, Secondary bank crisis, p. 60.
} 
than the preceding decade (figure 2, below). The oil shock of 1973 pushed lenders over the brink, and the secondary banks which had largely financed the boom had to be rescued by a Bank of England 'lifeboat'. 50

In 1976, Fforde did something unusual: he called in his memo of 1970, and placed a typewritten line in red on the first page: 'Interesting how various proposed safeguards got mostly swept away in the ensuing revolutionary tide.' The lesson from this episode was that theoretical models provided guidance that was incomplete, inadequate, or simply wrong (and not for the last time). Milton Friedman's doctrine of monetarism in the 1970s claimed that central banks could control the money supply by setting the interest rates and acting directly to regulate reserves in the banking system. The quantity theory implied that with firm control of the money supply, financial markets could be left to the forces of supply and demand. But after the 1970s, British monetary authorities completely failed to control the broad money supply M3, and monetarism was no help. American authorities did no better. ${ }^{51}$

IV

From the 1980s onwards there are two stories to tell, of money, and of housing. Credit controls were lifted again in January 1980 by the new conservative government. What made this possible was the windfall of North Sea oil, which firmed up the pound. ${ }^{52}$ Another measure was the sale of public housing to their tenants at big discounts. The stock of public housing was not replenished, and this eventually restricted supply and raised the cost of private housing. At a stroke, dwelling-house construction was cut in half. Before 1980, most housing finance in Britain was provided by building societies, which were mutual associations owned by their depositors and borrowers. Building societies only lent out of

\footnotetext{
${ }^{50}$ Reid, Secondary banking crisis; Goodhart, op. cit.

${ }^{51}$ Fforde, 'Setting monetary objectives'; Moore, Horizontalists and verticalists, pp. 74-86.

52 Dow, Inside the Bank of England, , pp. 161-162.
} 
what they took in as deposits, and any accumulated reserves. This limited the credit available for house purchase, and held prices down. ${ }^{53}$ They were not part of the clearing system, the payments system, or the interbank lending system, and had to rely on external bank accounts for access to these facilities. Unlike the banks, they could not conjure loans out of nothing. Commercial banks in England had never lent very much on the security of real estate, which they regarded as illiquid and difficult to realize. ${ }^{54}$ In the United States in the later nineteenth century, such lending was even notionally prohibited for national banks. ${ }^{55}$ In 1980 the prohibition against bank mortgage lending ended, 'arguably one of the most significant acts of deregulation of the UK financial sector in the post-war period. ${ }^{56}$ It effectively lifted the ceiling on housing credit. No deposit constraint affected the banks, which were able to lend at will to credible borrowers. ${ }^{57}$ In 1986 the building societies were allowed to convert into banks, thus removing their own constraints on lending. Convert they mostly did, drawing down the reserves accumulated by members over generations, and enriching their managers. A surge of lending followed, which reached the ceiling of borrowing capacity in the space of a few years (figure 2). All this was in tune with the spirit of the 'Big Bang' financial reform of 1986, in which investment banking in Britain was thrown open to the world.

\section{FIGURE 2 HERE}

In response to credit liberalization, between 1980 and 2008 UK banking sector assets (i.e loans, of both domestic banks and foreign ones in Britain) increased tenfold as a

\footnotetext{
${ }^{53}$ Hotson, Respectable Banking, pp. 29, 44.

${ }^{54}$ Offer, 'Narrow banking', pp. 161-165.

${ }^{55}$ Calomiris and Carlson, 'Corporate governance and risk management', pp. 17, 22.

${ }^{56}$ Hotson, Respectable banking, p. 168.

${ }^{57}$ Hotson, 'Respectable banking', ch. 4.
} 
proportion of national income. ${ }^{58}$ A narrower measure of lending, domestic borrowing as a percentage of national income, shows a fourfold increase, from about one half of GDP to more than 200 percent. In 2008, about 80 percent of UK commercial bank assets were secured on real estate. ${ }^{59}$ Figure 2 shows that the expansion of lending in the European Union and United States followed a similar pattern, though Britain's increase after the 1980s was steeper.

Such rapid expansions of credit are a challenge to monetary theory, especially to the exogenous variant. Where did the money come from? Credit expansions took place while monetarist-influenced Treasuries and central banks were striving to restrain the money supply in order to control inflation. But the successful suppression of retail prices automatically increased house values. When interest rates go down, the value of fixed-income assets rises proportionately (housing can be regarded as a fixed income asset, because rent levels are not much affected by interest rates). Low interest rates then make it easier to borrow, and high capital values make it easier to lend, in a 'credit-collateral spiral'. ${ }^{60}$ Where the money came from is not for us to decide here - the issue is not yet resolved. Suffice it to say that once controls were lifted, credit expanded rapidly. The increases appear to have been both exogenous and endogenous. New opportunities attracted yield-hungry funds from exportsurplus countries overseas and from the wealthy at home, whose tax liabilities had been cut by business-friendly governments. The same opportunities in mortgage finance also emboldened creators of keyboard money to raise bank leverage. ${ }^{61}$ Between 2000 and 2008, the median ratio of leverage (assets over capital) rose from over 20 to almost $50 .{ }^{62}$ But if both debt and credit expanded rapidly, that was not by design.

\footnotetext{
${ }^{58}$ Haldane and Alessandri, 'Banking on the State', Chart 1, p. 23.

${ }^{59}$ Independent Commission, Final report figure 3.4, p. 51; Great Britain, House of Commons, Treasury Select Committee, Too important to fail, Lord Turner’s evidence, 2 March 2010, Ev83.

${ }^{60}$ Stiglitz, 'The theory of credit', p. 25.

${ }^{61}$ Werner, 'Towards a new monetary paradigm' is generally consistent with this account.

${ }^{62}$ Independent Commission on Banking, Final report, figure 5.4, p. 128. Generally consistent with
} 
The new financial opportunity that opened up was housing. Money was not easy to lend in the 1980s. Because of de-industrialisation, there was a shortage of productive investments at home. In housing, banks discovered the ideal asset. The collateral was literally built in. Housing is both a subsistence and a status good. Demand is limited only by income. Housing is also the largest single consumer expenditure. Together with transport (a complement of housing-more distant locations pay lower rents but require more travel) housing amounts to more than 45 percent of consumer expenditure in Britain and the USA, up from less than 30 percent in the 1920s. ${ }^{63}$

Everyone requires a roof, and housing competition is impossible to opt out of. With little new social housing and strict zoning restrictions, housing became increasingly scarce. Its cost captured a rising share of rising incomes. Women worked more hours for wages, household incomes expanded to support rising debt service, and lenders lent out higher multiples of borrower incomes. ${ }^{64}$

Owner occupation had long been part of the ideology of English conservatism, and had a political constituency. ${ }^{65}$ Both main parties supported it. But it would be wrong to make too much of British circumstances. Similar policies were followed throughout Europe and the USA, regardless of political complexion. Owner occupation attracted tax privileges. Shareholders paid tax on their dividends. But in the UK for example, the imputed rental value of owner occupation was no longer taxed as income after 1963, and mortgage interest was deductible from income tax as it still is in the United States. There was no capital gains tax on the primary residence, and inheritance tax was restricted to expensive houses. Higher rate tax rate depositors in building societies paid less tax on their savings there. Local taxation of housing was regressive, and in the late 1980s, the Conservative UK government devised a

\footnotetext{
${ }^{63}$ Offer, 'Consumption and affluence, c. 1870-2010', pp. 212-217; For the USA, the same point (with different measures) in La Cava, 'Housing prices', p. 5.

${ }^{64}$ Muellbauer, 'When is a housing market overheated?’; Offer, 'British manual workers’, fig. 4, p. 551.

${ }^{65}$ Francis, '”Crusade to enfranchise”'.
} 
uniform head tax for housing which provoked evasion and even riots. When this 'poll tax' was withdrawn, the one that replaced it was still regressive. More recently, tax abatements for low earners have been withdrawn, and new subsidies introduced as 'Help to Buy', with an upper limit of about twice as much as the average house price in England and Wales. ${ }^{66}$ As an attempt to subsidise home ownership it was futile. Low taxes merely liberated income from taxation to pay for higher levels of debt service, thus pushing up house prices, and creating a windfall for those whose houses had already been paid off.

\section{V}

With credit liberalised, household debt rose steeply after 1980 (figure 3). It rose threefold in relation to income in the UK, and rises in other countries were comparable. Some of the highest levels of indebtedness and its growth were reached in social-democratic countries.

\section{FIGURE 3 HERE}

All this debt paid off for those who took it on. In the aggregate, housing wealth grew much more than debt (figure 4).

\section{FIGURE 4 HERE}

In figure 4, the bottom part of the columns (below the zero line) represents household debt. The segment above it is housing wealth, which rose as debt was paid down over time. The next segment up is pension wealth. The top one, made up mostly of financial wealth is largely a balancing item for debt, and is only held by a small minority of households. ${ }^{67}$

\footnotetext{
${ }^{66}$ Barrett, 'Help to Buy?'; Grice, 'Chancellor warned'.

${ }^{67}$ Mian and Sufi, House of debt, p. 18.
} 
Housing credit created a property windfall society, with the prospect of a free lunch for everybody. In the quest for economic security, the best personal strategy is to be rich. Housing wealth held out the promise of financial security for a growing part of the population, as an alternative and complement to social insurance, and another pillar of personal security. It may even be regarded as the next progressive innovation beyond social insurance. A more educated and middle-income society aspired to a nest egg to supplement and even replace the organized reciprocity of social democracy.

\section{FIGURE 5 HERE}

Figure 5 shows the proportions of households in Europe by tenure status. In all European countries except Switzerland more than half of all households signed up for owner occupation, thus ensuring the support of a political majority. It is a curiosity that the highest levels of paid-off owner occupation can be found in the successor countries of the old Soviet bloc, due perhaps to the way in which housing was privatized. In the more developed part of the EU the proportion of paid-off housing was never more than 50 percent, and was only about a quarter in the UK. This quarter of households were the ultimate beneficiaries of the post-1970s policy and the ones most heavily invested in it.

Easy credit carries a social cost. De-regulation drives inequality and financial instability. As house prices rose debt service captured a rising share of consumer expenditure. The labour share of income was falling everywhere. ${ }^{68}$ The reason was not only stagnating wage income

\footnotetext{
${ }^{68}$ ILO, Global Wage Report, pp. 41-45.
} 
(which did not happen everywhere). The share of capital was rising as it captured a rising share of national income for debt service. In the United States for example, almost all the rise in the share of capital can be explained by the rise in house values. ${ }^{69}$ This increase was shared between those who provided the finance, and by owner occupiers in proportion to the equity accumulated.

In the UK, the financial, business services and real estate sectors rose from about $17 \%$ of GDP value added in 1970 to about 35\% in 2006, neatly reversing ranking and magnitudes with manufacturing. ${ }^{70}$ Debt service payments crowded out consumption, and also production and services catering to consumption. It was a transfer from consumers to hoarders, from public goods, financed by taxation, to rentiers and lenders. Lenders spend only a small proportion of their incomes - that is why they lend in the first place. In contrast, social spending transfers resources to those with the highest propensity to spend. Debt service depresses demand, economic activity and public services. By pushing up the cost of living, debt service also priced labour out of international competition, and was implicated in the UK's large and chronic trade deficit. As debt service increases, output volatility does as well: marginal borrowers lose their jobs and are unable to service loans. A housing downturn also slows down construction and employment. The transition from optimism to pessimism quenches the wealth-effect spending of paid-up owners.

Even a small downturn was enough to destabilise the banks, with their high leverage. But most banks were not allowed to fail. They were bailed out, albeit sometimes at a loss to the shareholders. In consequence, and also due to the long recession that followed, public debt increased. Austerity was then imposed on public spending, but this only worked to raise the debt and especially to squeeze social democracy. That may have been the intention,

\footnotetext{
${ }^{69}$ Rognlie, 'Deciphering the fall and rise in net capital share'.

${ }^{70}$ Offer, 'Economy of obligation', fig. 4, p. 33.
} 
following the logic of disaster capitalism, in which the opportunity of a crisis is used to push through partisan policies. ${ }^{71}$

In the property windfall economy, early movers did best. The 'Great Moderation', the long period of low interest rates which formed the policy target statistic of the newly independent central banks, acted to raise house prices. Gradually house purchase rose beyond the reach of low earners. This was already becoming evident in the 1990s. If it required two incomes to support house-purchase, marriage was actually fraying during these decades, with almost fifty percent ending in divorce in the USA, and a growing number of single-head households, with and without children. ${ }^{72}$

A social divide began to grow, between those on the property ladder, and those unable to reach its first rung. A new 'generation rent' suffered insecure, expensive and inadequate housing, without much hope of ownership except by means of bequests. ${ }^{73}$ The only secure way to afford housing was to work for the lenders, i.e. get a job in finance. This has diverted talent away from socially useful work, and has undermined more productive parts of the economy.

Two separate items appeared in the London Guardian on the $14^{\text {th }}$ Of May 2016. One headline read 'Young families priced out of rental market in two thirds of the UK'; the other alluded to the fortunes of the erstwhile leader of Britain's social democratic party: 'Tony and Cherie Blair’s property empire worth estimated £27m', comprising of 'at least 10 houses and 27 flats between them, including several in central London’. Generational frustration and anger has welled up in support of such political aspirants as Corbyn, Sanders, Trump and Le Pen.

\footnotetext{
${ }^{71}$ Klein, The shock doctrine.

${ }^{72}$ Offer, Challenge of affluence, pp. 248-264, 284, and ch. 14; especially figure 4, p. 254; Offer, 'British manual workers', fig. 4, p. 551.

73 E.g., Insley, 'Private rents unaffordable'; Ellliott and Osborne, 'Under-35s in the UK'; Generation rent website, www.generationrent.org.
} 
For those on the property ladder, most of their productive life is spent servicing housing debt. With the connivance of politicians, lenders are reaching out further to divert labour income out of the tax base to support new forms of debt. Higher education, once provided on the social democratic model out of taxation, now requires a great deal of debt. Pensions, healthcare, transport and the utilities for energy and water supply are also being privatised. Their infrastructure has been paid for (in the UK) to financial intermediaries by means of the expensive Private Finance Initiative (PFI). That debt is serviced out of labour income through taxation and high user fees.

Debt is sustainable and even desirable if it produces more output than the cost of debt service. If it does not, its share of income continues to grow by means of compound interest. When the debt service rate of interest is higher than economic growth, then debt services takes a growing share of national output, reduces the reward for labour and for entrepreneurial capital, and diminishes demand, thus abating growth in the following year. ${ }^{74}$ Figure 6 is consistent with this story: the contraction of demand brings about a financial crash when loss of income affects the ability to service debt, especially mortgage debt. This figure shows an association between high debt service and financial crisis. It was compiled in an empirical quest to identify leading indicators for financial crises. The authors found that debt service as a ratio of personal income was the best predictor. Similar patterns

\section{FIGURE 6 HERE}

have been traced by other scholars over much longer periods. ${ }^{75}$ This is strong circumstantial evidence that debt service squeezed out demand and precipitated economic downturns.

\footnotetext{
${ }^{74} \mathrm{Koo}$, 'The world in balance sheet recession'; Bezemer and Hudson, 'Finance is not the Economy'.

75 Jorda et al, 'When credit bites back.'; Keen, 'The seven countries most vulnerable to a debt crisis'; additional references listed in Bezemer and Hudson, 'Finance is not the economy’, pp. 754-756.
} 
In the meantime, debt continues to grow. From 2007 to 2014, global debt outstanding rose from 269 percent to 286 per cent of global GDP. ${ }^{76}$ Social democracy redistributes for the benefit of health, education, social housing, and the needy. Market liberalism pays for privatised health, education, pensions, housing. It recycles debt into more and higher debt. It funds charity and substitutes it for entitlement. In the spring of 2016, both social democracy and market liberalism were stretched to the limit. The welfare state was being squeezed in the name of good housekeeping and austerity, notionally in order to reduce the public debt. At the same time, private debt service, at around 25 percent of private non-financial income in the UK and much the same elsewhere, was in the danger zone for financial crises. ${ }^{77}$ Private and public debt are at record peacetime levels. Austerity is reducing disposable income, and the decline of income requires government to assume more rather than less debt.

What is to be done? Policy is not the task of economic historians but the options are instructive. There are two issues each of which may require different approaches. The first is the immediate problem of debt overhang, the second to devise a regime to prevent its recurrence. The solutions being discussed break away from the previous consensus.

Induce inflation in order to reduce the real debt? That is how the debt overhang of World War II was overcome, but it would require quite high inflation over a long period of time. Write off debt selectively or universally? If a debt cannot be repaid, it will not be. Does it make sense to restructure or forgive? ${ }^{78}$ There is a venerable tradition of jubilees in which

\footnotetext{
${ }^{76}$ Dobbs et al., 'Debt (and not much) delevaraging', p. 1.

${ }^{77}$ Drehmann and Juselius, 'Do debt service costs?', pp. 25-6; Wolf, The shifts and the shocks, pp. 248-51.

${ }^{78}$ Mian and Sufi, House of debt, ch. 10; Turner, Between debt and the devil, pp. 224-230; Wolf, The shifts and the shocks, pp. 272-74.
} 
debts were cancelled. ${ }^{79}$ But the web of debt is complicated and it is hard to know where the cost will fall. For example, pensioners, both private and public, are creditors of mortgage providers. Some drastic ideas combine debt write-offs with the re-assertion of government's authority to issue money, ${ }^{80}$ and for governments to buy up private debt. A good deal of quantitative easing has already done exactly that.

The second challenge is how to avoid another debt crisis. The preferred solution is higher capital requirements for the banks, to reduce their leverage. ${ }^{81}$ It is hard to believe that this will be effective. At the levels at which it is proposed, between five and 10 percent of bank assets, depending on definitions, any requirement for more capital during the boom phase can be met by the ability of commercial banks to generate credit almost at will for the purchase of their capital. This will be less costly than the value of the additional business generated. Barclays bank was even able to do this at the depth of the crisis, by lending £3bn to Qatar to fund the purchase of its own shares. Regulators averted their gaze. ${ }^{82}$ Another option is to revert to credit rationing. Several mechanisms might bring deposit finance and mortgage loan maturities into better alignment, including a return to mutual society intermediation. ${ }^{83}$ It might also possible to ration speculative credit and to channel it to productive activities. ${ }^{84}$ Finally, a good deal of the housing problem arises not from excess demand but from the shortfall of supply. One solution might be to subsidise and build for those on lower incomes. This may be preferable to dismantling the zoning and planning systems which protect the environment where land is scarce.

These are be drastic solutions. All of them, one way or another, take away the free lunch of rising house values. Can society cope? If social insurance and owner-occupation are

\footnotetext{
${ }^{79}$ Graeber, Debt, pp. 80-5; 390-91.

${ }^{80}$ Turner, op. cit, ch. 15; Wolf, The shifts and the shocks, pp. 351, 381-82.

${ }^{81}$ Admati and Hellwig, The bankers' new clothes, pt. II; Independent Commission on Banking, Final Report, ch. 4.

${ }^{82}$ Miller, 'Barclays guilty of fraud'.

${ }^{83}$ Goodhart and Perotti, 'Maturity mismatch stretching'; Offer, 'Narrow banking', pp. 172-73.

${ }^{84}$ Werner, 'Comment', p. 9.
} 
the twin pillars of contemporary welfare, taking one of them away is going to confound expectations. But for one part of the population, the punchbowl has already been taken away. About 45 percent of UK households live in rented accommodation, under conditions of tenure that were getting worse, and a cost that continues to rise faster than incomes. Many of house buyers find that debt service is a struggle. If interest rates rise, they may find it impossible. Doing nothing may win some time until the next financial crisis. Maybe that is an advantage. We do not know precisely who is going to be hurt and how. Quite reasonably in April 2016, the date of this lecture, the choice appeared to be for a drastic crisis later, in preference to drastic action now.

\section{Footnote references}

Admati, A. R., and Hellwig, M. F., The bankers' new clothes: What's wrong with banking and what to do about it (Princeton, New Jersey, 2015).

Alvaredo, F., Atkinson, A. B., Piketty, T., and Saez, E., 'The top 1 percent in international and historical perspective’, Journal of Economic Perspectives, 27, 3 (2013), pp. 3-20.

Bacon, R. W., and Eltis, W., Britain's economic problem: Too few producers (London, 1976).

Bank of England, 'Competition and credit control', Bank of England Quarterly Bulletin, 11 (1971), pp. 189-93.

Barr, N. A., The welfare state as piggy bank: Information, risk, uncertainty, and the role of the state (Oxford, 2001).

Barrett, C., ‘Help to buy? More like help to cry for London’s first-time buyers’, Financial Times, 11 February (London, 2016). 
Berman, S., 'The folkhem was a success story', in Almqvist, K., Glans, K. and Fischer, P. (eds.), The Swedish success story? (Stockholm, 2004), pp. 61-65.

Bezemer, D., and Hudson, M., 'Finance is not the economy: Reviving the conceptual distinction', Journal of Economic Issues, 50 (2016), pp. 745-68.

Burtless, G., 'Social security privatisation and financial market risk: Lessons from US financial history', in Ihori, T. and Tachibanaki, T. (eds.), Social security reform in advanced countries: Evaluating pension finance (London, 2002), pp. 52-80.

Calomiris, C. W. and Mark, C., 'Corporate governance and risk management at unprotected banks: National banks in the 1890s’, National Bureau of Economic Research, working paper 19806, January (Boston, 2014).

Capie, F., The Bank of England: 1950s to 1979 (Cambridge; New York, 2010).

Cingano, F., ‘Trends in income inequality and its impact on economic growth', OECD Social, employment and migration working papers 163 (Paris, 2014).

Cornes, R., and Sandler, T., The theory of externalities, public goods, and club goods (Cambridge, 1986).

Dabla-Norris, E., Kochhar, K., Suphaphiphat, N., Ricka, F., and Tsounta, E., 'Causes and consequences of income inequality: A global perspective’, International Monetary Fund, June (Washington DC, 2015).

Davies, A. R., “'right to buy’: The development of a conservative housing policy, 1945 1980’, Contemporary British History, 27, 4 (2013), pp. 421-44.

Diamond, D. W., and Dybvig, P. H., 'Bank runs, deposit insurance, and liquidity’, Journal of Political Economy, 91, 3 (1983), pp. 401-19.

Dobbs, R., Lund, S., Woetzel, J., and Mutatchieva, M., 'Debt and (not much) deleveraging', McKinsey Global Institute, February (London, 2015). 
Drehmann, M., and Juselius, M., 'Do debt service costs affect macroeconomic and financial stability?’ BIS Quarterly Review , September (2012), pp. 21-35.

Elliott, L., and Osborne, H., 'Under-35s in the UK face becoming permanent renters, warns think tank’, The Guardian, 13 February 2016.

Feldstein, M., 'Rethinking social insurance’, American Economic Review, 95, 1 (2005), pp. 124.

Fforde, J., 'Banking system (and credit control)’ 24 December 1970, Bank of England archive, 3A8/9.

Fforde, J. S., 'Setting monetary objectives', in Meek, P. (ed.), Central bank views on monetary targeting: Papers presented at a conference held at the federal reserve bank of New York, May 1982 (New York, 1982), pp. 200-09.

Francis, M., “A crusade to enfranchise the many': Thatcherism and the 'property-owning democracy’, Twentieth Century British History, 23, 2 (2012), pp. 275-97.

Frank, R. H., Microeconomics and behavior (New York; London, 1991).

Friedman, M., There’s no such thing as a free lunch (LaSalle, Ill., 1975).

Friedman, M., and Friedman, R. D., Capitalism and freedom (Chicago, 1962).

Friedman, M., A theory of the consumption function (Princeton, 1957).

Gaffney, M., and Harrison, F., Corruption of economics (London, 1994).

Generation rent website, www.generationrent.org.

George, H., Progress and poverty: An inquiry into the cause of industrial depressions and of increase of want with increase of wealth: The remedy (London, 1881).

Goldman, L., The life of R. H. Tawney: Socialism and history (London, 2013).

Goodhart, C. A. E., 'Competition and credit control', London School of Economics, LSE Financial Markets Group Special Paper Series 229, March (London, 2014). 
Goodhart, C. A. E., and Perotti, E., 'Maturity mismatch stretching: Banking has taken a wrong turn', Unpublished paper (London, 2016).

Graeber, D., Debt: The first 5,000 years, Updated and expanded edn. (London, 2014).

Grice, A., 'Chancellor warned ‘mad’ help-to-buy scheme could drive up house prices', The Independent, 23 July 2013.

Haldane, A. G., and Alsessandri, P., 'Banking on the state', Bank of England, unpublished paper, 6 November (London, 2009).

Hines, J. R., 'Three sides of Harberger triangles', Journal of Economic Perspectives, 13, 2 (1999), pp. 167-88.

Hirsch, F. and Goldthorpe, J. H., eds., The political economy of inflation (London, 1978).

Hotson, A. C., Respectable banking: The search for stability in London's money and credit markets since 1695 (forthcoming, Cambridge, 2017).

Hudson, M., The bubble and beyond: Fictitious capital, debt deflation and the global crisis (Dresden, 2012).

Independent Commission on Banking., Final report: Recommendations (London, 2011).

Insley, J., 'Private rents unaffordable for families in most English boroughs', The Guardian, 13 October 2011.

International Labour Office (ILO), Global wage report 2012/13: Wages and equitable growth (Geneva, 2013).

Isaksen, J., Kramp, P. L., Sørensen, L. F., and Sørensen, S. V., 'Household balance sheets and debt - an international country study', Danmarks Nationalbank Monetary Review, $4^{\text {th }}$ Quarter, 1 (2011), pp. 47-58.

Jorda, O., Schularick, M., and Taylor, A. M., 'When credit bites back: Leverage, business cycles, and crisis’, Federal Reserve Bank of San Francisco, working paper 2011-27, October (San Francisco, Calif., 2011). 
Kaldor, N., ‘The new monetarism’, Lloyd’s Bank Review 97, (July 1970), pp. 1-18.

Kareken, J. H., 'Monetary policy’, in Caves, R. E. (ed.), Britain’s economic prospects (London, 1968), pp. 68-103.

Keen, S., 'The seven countries most vulnerable to a debt crisis’ (2016), in https://rwer.wordpress.com/?s=seven+countries+most, (accessed: 3 April 2016).

Klein, N., The shock doctrine: Rise of disaster capitalism (London, 2007).

Koo, R. C., ‘The world in balance sheet recession: Causes, cure, and politics', Real-world economics review 58 (2011), pp. 19-37.

La Cava, G., 'Housing prices, mortgage interest rates and a rising share of capital income in the united states’, Bank of International settlements, BIS Working papers , 527, July (Basel, 2016).

Lerner, M. J., The belief in a just world: A fundamental delusion (New York, 1980).

Lipsey, R. G., and Lancaster, K., 'The general theory of second best', Review of Economic Studies, 24 (1956), pp. 11-32.

Lucas, R. E., 'Monetary neutrality’, Nobel Prize Lecture, The Nobel Foundation, 7 December 1995 (Stockholm, 1995).

McLeay, M., Radia, A., and Ryland, T., 'Money creation in the modern economy', Bank of England Quarterly Bulletin, Q1 (2014), pp. 1-14.

Mian, A., and Sufi, A., House of debt: How they (and you) caused the great recession, and how we can prevent it from happening again (Chicago, 2015).

Miller, R., 'Barclays “guilty of fraud over £3bn loan to Quatar”،, The Times, 2 September 2016.

Mishkin, F. S., The economics of money, banking, and financial markets (Boston, Mass.; London, 2007). 
Modigliani, F., 'Life-cycle, individual thrift and the wealth of nations', in Mäler, K.-G. (ed.), Nobel lectures including presentation speeches and laureates’ biographies (Singapore, 1992), pp. 150-71.

Monnet, E., 'The diversity in national monetary and credit policies in western Europe under the Bretton Woods system', in Les banques centrales et les états: Banques centrales et construction de l'état-nation (xix et xxe siècle) (Paris, 2014).

Moore, B. J., Horizontalists and verticalists: The macroeconomics of credit money (Cambridge, 1988).

Muellbauer, J., 'When is a housing market overheated enough to threaten stability?' in Heath, A., Packer, F. and Windsor, C. (eds.), Property markets and financial stability (Sydney, NSW, 2012), pp. 73-105.

O’Brien, D. P., The classical economists (Oxford, 1978).

Offer, A., Property and politics, 1870-1914: Landownership, law, ideology and urban development in england (Cambridge, 1981).

Offer, A., 'Between the gift and the market: The economy of regard', Economic History Review, 50, 3 (1997), pp. 450-76.

Offer, A., The challenge of affluence: Self-control and well-being in the united states and britain since 1950 (Oxford, 2006).

Offer, A., 'British manual workers: From producers to consumers, c. 1950-2000', Contemporary British History, 22, 4 (2008), pp. 537-71.

Offer, A., 'The economy of obligation: Incomplete contracts and the cost of the welfare state', University of Oxford discussion papers in economic and social history, 103 (Oxford, 2012). 
Offer, A., ‘Consumption and affluence, c. 1870-2010’, in Floud, R., Humphries, J. and Johnson, P. (eds.), The Cambridge economic history of modern Britain, vol. 2, 1870 to the Present (Cambridge, 2014), pp. 205-28.

Offer, A., 'Narrow banking, real estate, and financial stability in the UK, c. 1870-2010', in Dimsdale, N. and Hotson, A. (eds.), British financial crises since 1825 (Oxford, 2014), pp. 158-73.

Offer, A., and Söderberg, G., The Nobel factor: The prize in economics, social democracy and the market turn (Princeton, New Jersey, 2016).

Okun, A. M., Equality and efficiency: The big tradeoff (Washington, D.C, 1975).

Organisation for Economic Co-operation and Development (OECD), The welfare state in crisis: An account of the conference on social policies in the 1980s, OECD, Paris, 2023 October 1980 (Paris, 1981).

Osberg, L., 'The equity/efficiency trade-off in retrospect', Dalhousie University (Halifax, Nova Scotia, 1995).

Ostry, J. D., Berg, A., and Tsangrides, C. G., 'Redistribution, inequality, and growth', International Monetary Fund Research Department , SDN/14/02, February (Washington, DC, 2014).

Palley, T. I., 'Horizontalists, verticalists, and structuralists: The theory of endogenous money reassessed', Institut für makroökonomie und konjunkturforschung, Working paper 131, June (Düsseldorf, 2013).

Phelps, E. S., Rewarding work (Cambridge, Mass., 1997).

Piketty, T., Capital in the twenty-first century (Cambridge, Mass., 2014).

Rawls, J., A theory of justice (Cambridge, Mass., 1971).

Reid, M., Secondary banking crisis, 1973-75: Its causes and course (London, 1982). 
Rognlie, M., 'Deciphering the fall and rise in the net capital share: Accumulation or scarcity?’ Brookings Papers on Economic Activity, March (2015), pp. 1-69.

Rubin, Z., and Peplau, L. A., 'Who believes in a just world?' Journal of Social Issues, 31, 3 (1975), pp. 65-89.

Ryan-Collins, J., Where does money come from?: A guide to the UK monetary and banking system, 2nd edn. (London, 2012).

Samuelson, P. A., 'An exact consumption-loan model of interest with or without the social contrivance of money', Journal of Political Economy, 66, 6 (1958), pp. 467-82.

Samuelson, P. A., and Nordhaus, W. D., Economics, 13th edn. (New York; London, 1989).

Sayers, R. S., Modern banking, 7th edn. (Oxford, 1967).

Shehab, F., Progressive taxation: A study in the development of the progressive principle in the British income tax (Oxford, 1953).

Shiller, R. J., Finance and the good society (Princeton, N.J.; Oxford, 2012).

Steger, T., Knoll, K., and Schularick, M., ‘No price like home: Global house prices,18702012', Verein für sozialpolitik, beiträge zur jahrestagung des vereins für socialpolitik 2015: Ökonomische entwicklung--theorie undpolitik - Session: Housing and the macroeconomy [C06-V2] (2015).

Stiglitz, J. E., Economics (New York; London, 1993).

Stiglitz, Joseph E., 'The theory of credit and macro-economic stability’, NBER Working paper 22837 (Cambridge, MA, 2016).

Turner, A., Between debt and the devil: Money, credit and fixing global finance (Princeton,

Werner, R. A., ‘Towards a new monetary paradigm: A quantity theorem of disaggregated credit, with evidence from Japan', Kredit und kapital, 30, 2 (1997), 276-309.

Werner, R. A., Princes of the yen: Japan's central bankers and the transformation of the economy (Armonk, New York; London, 2003). 
Werner, R., New paradigm in macroeconomics: Solving the riddle of Japanese macroeconomic performance (Basingstoke, 2005).

Werner, R. A., 'Comment: Strengthening the resilience of the banking sector' (unpublished paper, Southampton, 2010).

Werner, R. A., 'Can banks individually create money out of nothing?--the theories and the empirical evidence’, International Review of Financial Analysis, 36, December (2014), pp. 1-19.

Werner, R. A., 'A lost century in economics: Three theories of banking and the conclusive evidence', International Review of Financial Analysis (2015), pre-publication online, http://dx.doi.org/10.1016/j.irfa.2015.08.014. (accessed 12 Feb. 2016).

Wolf, M., The shifts and the shocks: What we've learned - and have still to learn - from the financial crisis; with a new afterword (London, 2014).

Wolff, E. N., Top heavy: A study of the increasing inequality of wealth in America, New updated edn. (New York, 1995). 


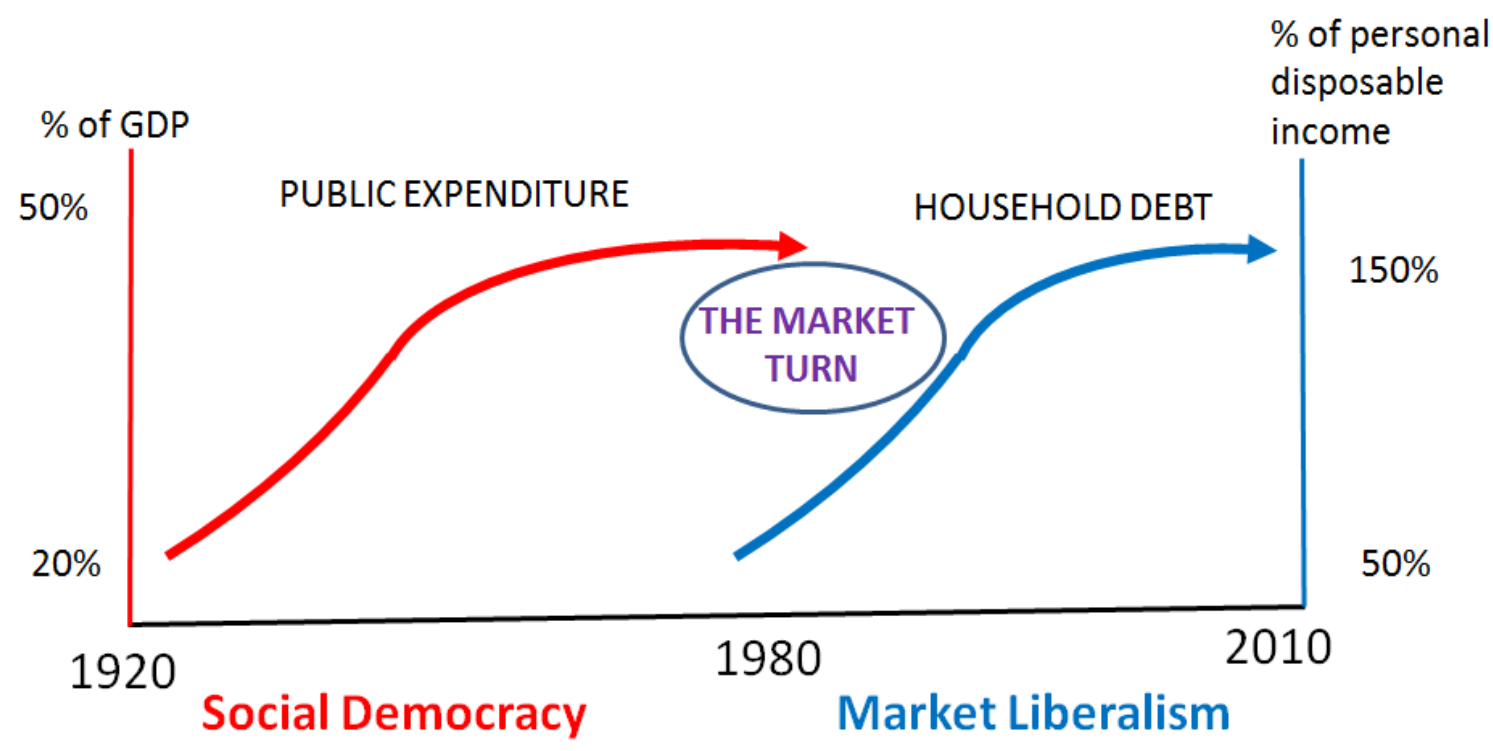

Figure 1. Two macroeconomic financial innovations in the $20^{\text {th }}$ century, UK calibration.

Note: Diffusion curves are schematic, not descriptive. 


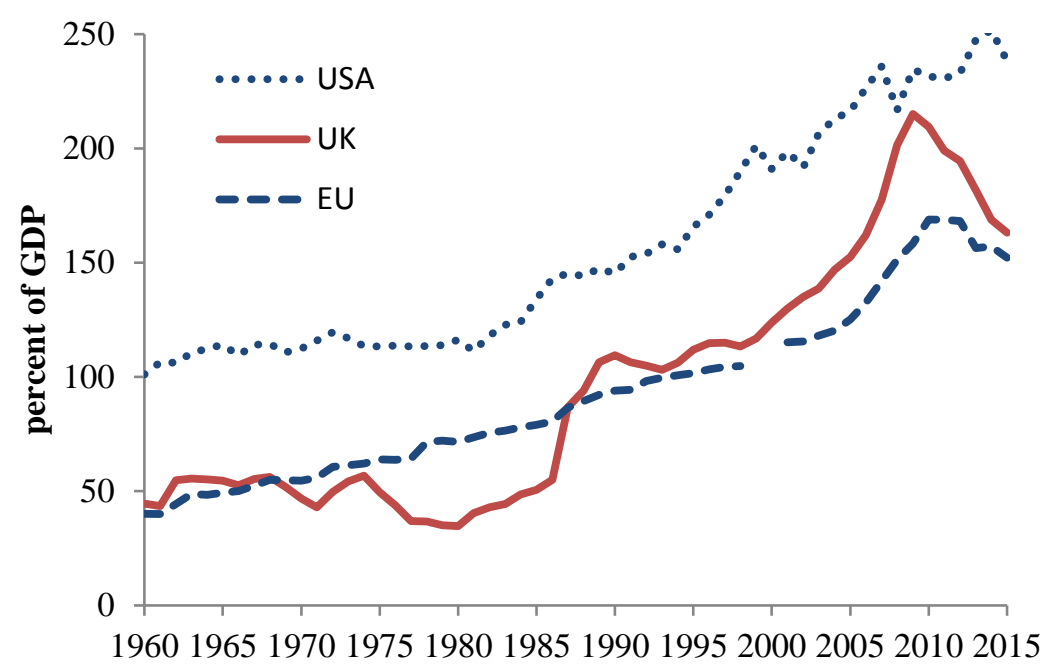

Figure 2. Domestic credit provided by financial sector, percent of GDP, USA, UK, EU.

Source: International Monetary Fund, International Financial Statistics and data files, and World Bank and OECD GDP estimates. 


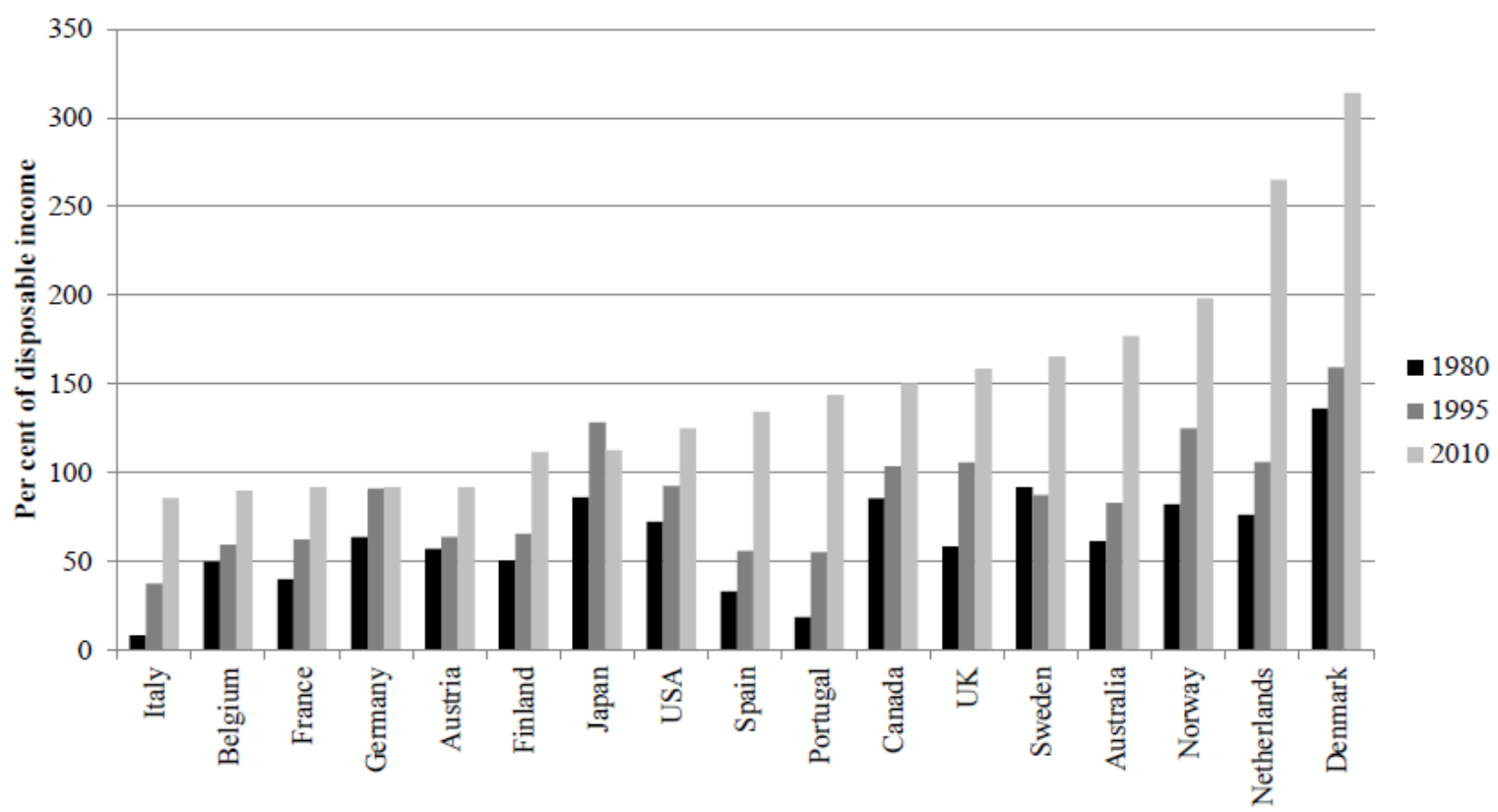

Figure 3. Household debt levels in selected OECD countries, as percentage of personal disposal income, 1980-2010.

Source: Data provided by Paul Lassenius Kramp , Danish national bank; see also Isaksen et al., 'Household balance sheets and debt', chart 3, p. 51. 


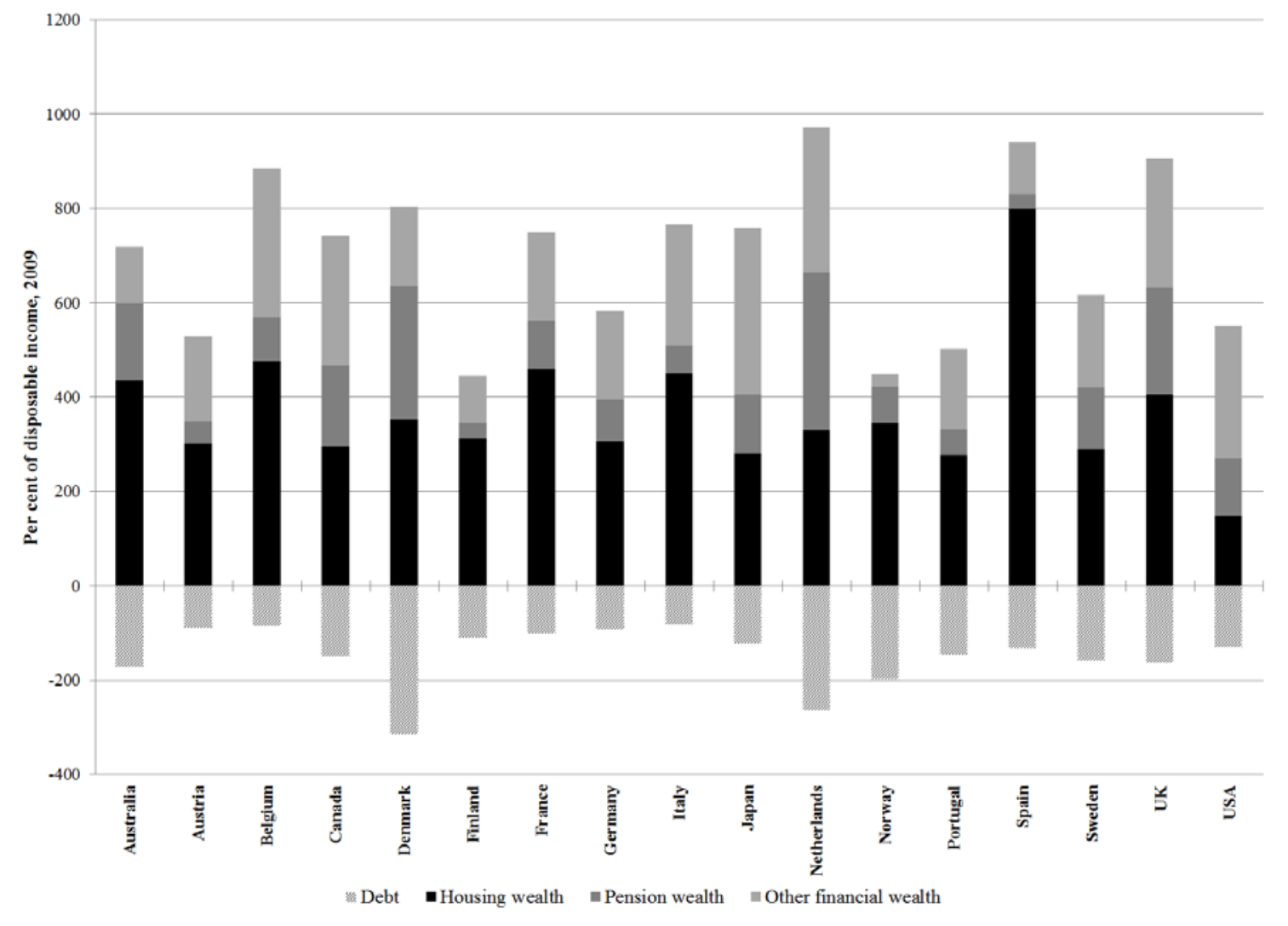

Figure 4. Household wealth and gross debt, selected OECD countries, 2009.

Source: Data provided by Paul Lassenius Kramp, Danish national bank; Isaksen et al., 'Household balance sheets and debt', chart 2, p. 50 . 


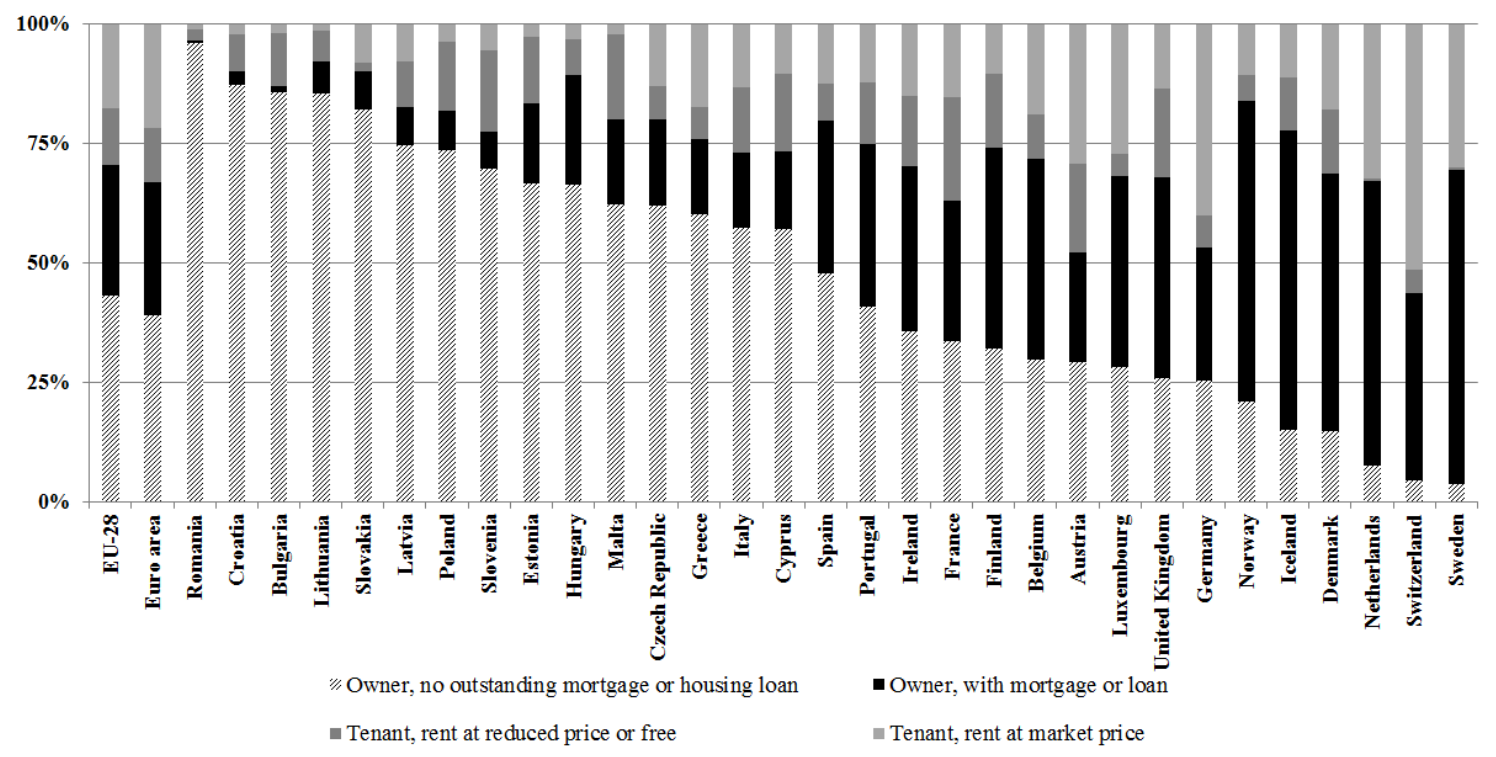

Figure 5. Percentage of households in different housing tenures, EU28, 2011.

Source:

Eurostat

ilc_Ivho02.

appsso.eurostat.ec.europa.eu/nui/show.do?dataset=ilc_lvho02\&lang=en. 
Australia

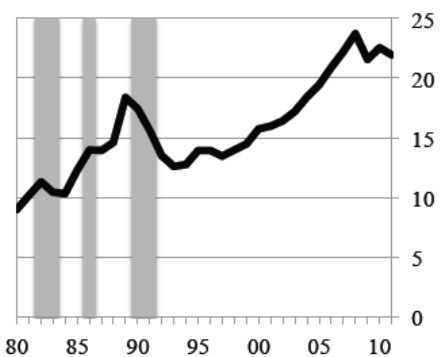

Korea

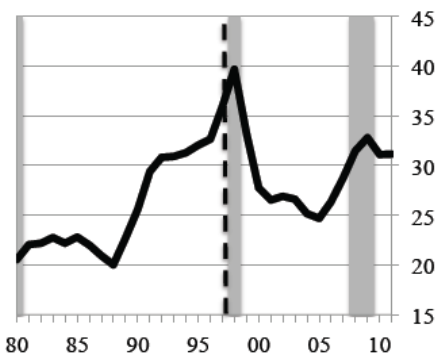

Finland

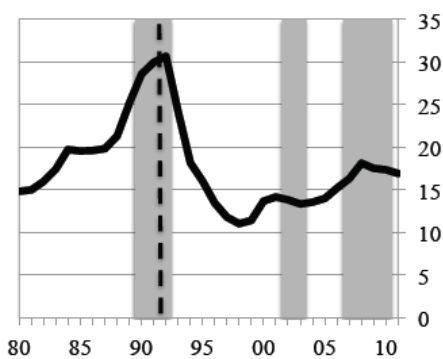

United Kingdom

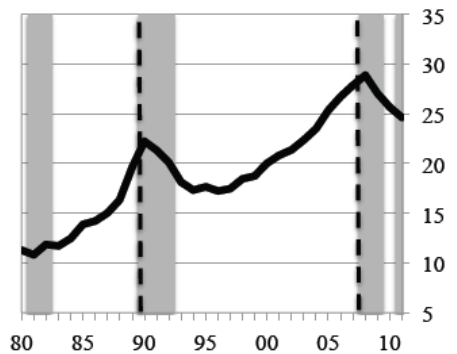

Italy

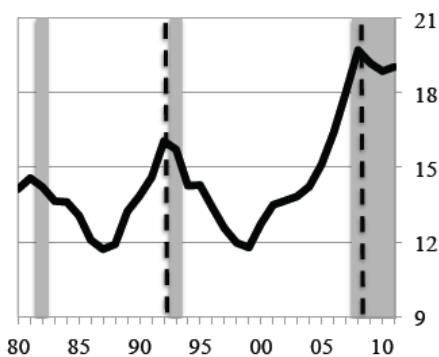

United States

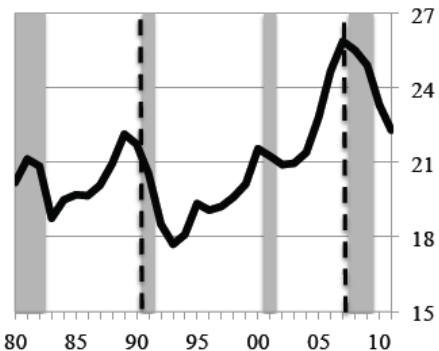

Figure 6. Debt service ratios as percent of private sector non-financial income (curves), and financial crisis dates (vertical lines and shading).

Source: Drehmann and Juselius, 'Do debt service costs?', graph 1, p. 26, and additional data courtesy of Matthias Drehmann, Bank of International Settlements. 